\title{
Lovastatin-Enriched Rice Straw Enhances Biomass Quality and Suppresses Ruminal Methanogenesis
}

\author{
Mohammad Faseleh Jahromi, ${ }^{1}$ Juan Boo Liang, ${ }^{1}$ Rosfarizan Mohamad, \\ Yong Meng Goh, ${ }^{3}$ Parisa Shokryazdan, ${ }^{4}$ and Yin Wan $\mathrm{Ho}^{4}$ \\ ${ }^{1}$ Institute of Tropical Agriculture, Universiti Putra Malaysia, 43400 Serdang, Selangor, Malaysia \\ ${ }^{2}$ Faculty of Biotechnology and Biomolecular Sciences, Universiti Putra Malaysia, 43400 Serdang, Selangor, Malaysia \\ ${ }^{3}$ Faculty of Veterinary Medicine, Universiti Putra Malaysia, 43400 Serdang, Selangor, Malaysia \\ ${ }^{4}$ Institute of Bioscience, Universiti Putra Malaysia, 43400 Serdang, Selangor, Malaysia
}

Correspondence should be addressed to Juan Boo Liang; jbliang@putra.upm.edu.my

Received 18 October 2012; Revised 22 December 2012; Accepted 28 December 2012

Academic Editor: Ayman El-Kadi

Copyright (c) 2013 Mohammad Faseleh Jahromi et al. This is an open access article distributed under the Creative Commons Attribution License, which permits unrestricted use, distribution, and reproduction in any medium, provided the original work is properly cited.

\begin{abstract}
The primary objective of this study was to test the hypothesis that solid state fermentation (SSF) of agro-biomass (using rice straw as model); besides, breaking down its lignocellulose content to improve its nutritive values also produces lovastatin which could be used to suppress methanogenesis in the rumen ecosystem. Fermented rice straw (FRS) containing lovastatin after fermentation with Aspergillus terreus was used as substrate for growth study of rumen microorganisms using in vitro gas production method. In the first experiment, the extract from the FRS (FRSE) which contained lovastatin was evaluated for its efficacy for reduction in methane $\left(\mathrm{CH}_{4}\right)$ production, microbial population, and activity in the rumen fluid. FRSE reduced total gas and $\mathrm{CH}_{4}$ productions $(P<0.01)$. It also reduced $(P<0.01)$ total methanogens population and increased the cellulolytic bacteria including Ruminococcus albus, Fibrobacter succinogenes $(P<0.01)$, and Ruminococcus flavefaciens $(P<0.05)$. Similarly, FRS reduced total gas and $\mathrm{CH}_{4}$ productions, methanogens population, but increased in vitro dry mater digestibility compared to the non-fermented rice straw. Lovastatin in the FRSE and the FRS significantly increased the expression of HMG-CoA reductase gene that produces HMG-CoA reductase, a key enzyme for cell membrane production in methanogenic Archaea.
\end{abstract}

\section{Introduction}

Over the last 250 years, the concentration of atmospheric methane $\left(\mathrm{CH}_{4}\right)$ increased by approximately $150 \%$ [1], with agricultural activities contributing $40 \%$ of the total anthropogenic source, of which 15 to $20 \%$ is from enteric fermentation in ruminants [2]. On the other hand, ruminal $\mathrm{CH}_{4}$ production accounts for between 2 and 15\% of dietary energy loss for the host animals [3]. Because of its negative effect on environment and the host animal nutrition, mitigation of enteric $\mathrm{CH}_{4}$ fermentation in ruminant livestock, including the use of various mitigating agents, such as ionophores [4], organic acids [5], fatty acids [6], methyl coenzyme M reductase inhibitors [7], and oil [8] has been extensively researched. However, these technologies have limited application primarily because besides suppressing $\mathrm{CH}_{4}$ they also suppressed nutrients digestibility and thus overall animal productivity.

Rice straw (RS) is one of the most abundant agricultural by-products, with nearly $90 \%$ of the world annual production in Asia [9]. The traditional method for disposing bulk of the RS after grain harvest is by burning [10] resulting in environmental pollution. On the other hand, ruminant animals can convert this fiber-rich biomass into high-quality animal protein (i.e., meat and milk) for human consumption. However, this highly efficient biological conversion of biomass into human food needs to be balanced against the concomitant production of $\mathrm{CH}_{4}$ which has often been 
implicated as source of greenhouse gases affecting global warming. Biological treatment has been shown to be able to hydrolyse the macromolecules of the lignocelluloses into usable nutrients and thus improved the quality of agricultural biomass as ruminant feed [11].

Lovastatin $\left(\mathrm{C}_{24} \mathrm{H}_{36} \mathrm{O}_{5}\right.$, M.W. 404.55) is a secondary product of idiophase (secondary phase) of growth of fungi [19] and is an inhibitor of enzyme 3-hydroxy-3-ethylglutaryl coenzyme A (HMG-CoA) reductase [EC 1.1.1.34], a key enzyme in cholesterol production pathway in humans [20]. There is a similarity between cholesterol formation in human and cell membrane formation in the Archaea as the lipid side of phospholipids in the cell membrane of Archaea is isoprenoid chains [21]. Isoprenoid formation is an intermediate step of cholesterol production pathway (Mevalonate pathway) and HMG-CoA reductase is also a key enzyme for its production [22]. Therefore, as an inhibitor of HMG-CoA reductase, lovastatin suppresses isoprenoid production and thus cholesterol synthesis and membrane formation in the Archaea. Wolin and Miller [23] showed that lovastatin significantly reduced growth and activity of pure methanogenic bacteria without any negative effect on cellulolytic bacteria. In their study, pure statin was added to the broth medium of individual bacteria without examining the effects of statin on the function of mixed rumen microorganisms. Moreover, pure statin is too expensive to be used as feed additive and thus has limited application for mitigation of $\mathrm{CH}_{4}$ in ruminants.

We have previously reported that Aspergillus terreus can be used to produce lovastatin in solid state fermentation (SSF) using RS as substrate with maximum production of $260.8 \mathrm{mg} / \mathrm{kg}$ DM lovastatin obtained after 8 days of fermentation [24]. The main objective of this study was to test the hypothesis that fungal treatment of agricultural biomass, using RS as model, can improve its nutritive value and in addition, as an agent for mitigation of $\mathrm{CH}_{4}$ without negatively affecting nutrient digestibility in the rumen ecosystem. To achieve the above, RS was fermented in SSF using Aspergillus terreus (ATCC74135) to produce lovastatin and to reduce its lignocelluloses content. Methanolic extract from the FRS containing lovastatin was evaluated for reduction of methanogenesis in rumen fluid using in vitro gas production technique and finally the potential of the fermented rice straw (FRS) as inhibitor of methanogenesis and efficiency of microbial degradability of the substrate were evaluated.

\section{Materials and Methods}

2.1. Substrate, Microorganism, and Spore Suspension. Fermented rice straw was prepared in SSF using A. terreus ATCC 74135 according to the method described previously [24]. The concentration of lovastatin in the FRS was $260.8 \mathrm{mg} / \mathrm{kg}$ DM after 8 days of fermentation [24] and the dried FRS $\left(60^{\circ} \mathrm{C}\right.$ for $48 \mathrm{~h}$ ) was used in the present study.

2.2. Transmission Electron Microscopy (TEM). The procedure of sample preparation by Hayat [25] with minor modified by the Electron Microscopy Unit, Institute of Bioscience,
Universiti Putra Malaysia, was used for the TEM study. The RS and FRS samples were cut into $1 \mathrm{~mm}$ and put in separated vials in triplicate and fixed in fixative solution (4\% glutaraldehyde) for 2 days at $4^{\circ} \mathrm{C}$. In the next step, samples were washed with $0.1 \mathrm{M}$ sodium cacodylate buffer for 3 changes of $30 \mathrm{~min}$ each. For postfixation, samples were kept in $1 \%$ osmium tetroxide for $2 \mathrm{~h}$ at $4^{\circ} \mathrm{C}$ and then washed again with $0.1 \mathrm{M}$ sodium cacodylate buffer for 3 changes of $30 \mathrm{~min}$ each. Samples were kept in different concentrations of acetone $(35,50,75$ and $95 \%)$ for 30 min each and finally in $100 \%$ acetone for 3 times of $1 \mathrm{~h}$ to dehydrate. For infiltration of the specimen, samples were dissolved into acetone-resin $(1: 1)$ for $4 \mathrm{~h}$, acetone-resin $(1: 3)$ for overnight, $100 \%$ resin over night, and finally $100 \%$ resin for $4 \mathrm{~h}$. In the next step, samples were put in beam capsules and filled up with fresh resin and kept in oven at $60^{\circ} \mathrm{C}$ for $48 \mathrm{~h}$ for polymerization. Glass knife and ultramicrotome were used to cut the samples into $1 \mu \mathrm{M}$ and samples placed onto glass slides, stained with toluidine blue, dried, washed the stain, and examined under light microscope. After selecting the area of interest, the sections were stained with uranyl acetate for $15 \mathrm{~min}$ and washed by distilled water for 3 times. Transmission electron microscopy observations were carried out using Transmission Electron Microscope (Hitachi H-7100, Japan).

2.3. Preparation of Methanolic Extract. For preparation of methanolic extract, $200 \mathrm{~g}$ of the FRS were mixed with $1.5 \mathrm{~L}$ of methanol and shacked for $2 \mathrm{~h}$ at room temperature. The solid sample was removed from the suspension using $0.45 \mu \mathrm{M}$ vacuum filter. Methanol from extract was removed by evaporation at $45^{\circ} \mathrm{C}$ using rotary evaporator (Eppendorf, USA). The concentration of lovastatin in the FRS extract was quantified using HPLC according to the method that described previously [24].

2.4. In Vitro Gas Production. Gas production was determined by the procedure described by Menke and Steingass [26]. For studying the effect of fermentation process on rumen microorganisms, two experiments of in vitro gas production were designed.

Experiment 1. The aim of this experiment was to examine the effect of fermented rice straw extract (FRSE) containing lovastatin on rumen fermentation, microbial activity, and population. In this study, $500 \mathrm{mg}$ of ground RS were transferred in $100 \mathrm{~mL}$ glass syringes (Haberle Labortechnik, Germany) followed by the addition of $200 \mu \mathrm{L}$ of methanol (control) while in the treatments, $10 \mathrm{mg}$ (treatment 1) and $20 \mathrm{mg}$ (treatment 2) of dry FRSE were dissolved in the $200 \mu \mathrm{L}$ methanol before the latter was added in the glass syringe contain $500 \mathrm{mg}$ RS.

Experiment 2. In this experiment, the FRS (containing lovastatin) was compared with RS to investigate their effect on microbial activity in the rumen ecosystem. $500 \mathrm{mg}$ of RS and FRS were transferred into $100 \mathrm{~mL}$ calibrated glass syringes (Haberle Labortechnik, Germany) for the in vitro 
gas production study and their effect on rumen microflora activity and population.

All treatments were replicated three times and repeated in two separate runs. Buffer and mineral solution [26] was prepared and placed in a $39^{\circ} \mathrm{C}$ water bath under continuous flushing with $\mathrm{CO}_{2}$. Rumen fluid was collected before the morning feeding from two rumen-fistulated steers fed an equal weight mixture of $40 \%$ concentrate and $60 \%$ grass hay twice daily at 0800 and $1800 \mathrm{~h}$. Rumen fluid was collected from the rumen with a manually operated suction pump and transferred into two prewarmed bottle, filtered through eight layers of cheesecloth, and flushed with $\mathrm{CO}_{2}$. Rumen fluid $(800 \mathrm{~mL})$ was added to the buffered mineral solution $(1600 \mathrm{~mL})$ with constant stirring, while maintained in a water bath at $39^{\circ} \mathrm{C}$. About $30 \mathrm{~mL}$ of buffered rumen fluid was transferred into syringes containing each treatment. The above procedures were conducted under continuous flushing with $\mathrm{CO}_{2}$. After closing the clips on the silicon tube attached to the syringe tip, syringes were gently shaken and the clips were opened to remove the gas by pushing the piston upwards to achieve complete gas removal. The clip was closed, the initial volume recorded, and the syringe was placed in the water bath incubator at $39^{\circ} \mathrm{C}$ for $48 \mathrm{~h}$. Standard hay (University of Hohenheim, Stuttgart, Germany) with an estimated gas production of $49.61 \mathrm{~mL} / \mathrm{g} \mathrm{DM}$ was used as a standard to calibrate the in vitro gas production system. Gas production was recorded at 2-hour intervals and at the end of the incubation the liquid layer of each syringe was sampled for $\mathrm{pH}$, volatile fatty acids analysis, bacterial quantification, and gene expression. In vitro dry matter digestibility (IVDMD) was determined according to Tilley and Terry [27].

2.5. Methane and Hydrogen Determination. The concentrations of $\mathrm{CH}_{4}$ and $\mathrm{H}_{2}$ in the headspace gas phase of syringes were determined by injecting $500 \mu \mathrm{L}$ of the gas from each sample to the gas chromatography (Agilent 6890 Series Gas Chromatograph, Wilmington, DE, USA). Separation of the gases was achieved using a HP-Plot Q column $(30 \mathrm{~m} \times$ $0.53 \mathrm{~mm} \times 40 \mu \mathrm{M}$ ) (Agilent Technologies, Wilmington, DE, USA). Nitrogen was used as carrier gas with flow rate of $3.5 \mathrm{~mL} / \mathrm{min}$ (MOX, Kuala Lumpur, Malaysia). The isothermal oven temperature was $50^{\circ} \mathrm{C}$ and the separated gases were detected using thermal conductivity detector in 4 min of run time. Calibration was completed using standard gas prepared by Scott Specialty Gases (Supelco, Bellefonte, PA, USA) which contain $1 \%$ of $\mathrm{CH}_{4}, \mathrm{CO}, \mathrm{CO}_{2}, \mathrm{O}_{2}$, and $\mathrm{H}_{2}$.

2.6. Volatile Fatty Acids Determination. After incubation, samples were centrifuged at $1340 \times \mathrm{g}$ for $10 \mathrm{~min}$ and $3 \mathrm{~mL}$ of the supernatant fluid were transferred to $15 \mathrm{~mL}$ centrifuged tube and $600 \mu \mathrm{L}$ of $24 \%$ metaphosphoric acid were added to acidify the samples and allowing the volatile fatty acids (VFA) to be vaporized in the gas chromatography injection port and the samples were kept for $24 \mathrm{~h}$ at room temperature. The samples were then centrifuged $(1340 \times \mathrm{g}$ for $20 \mathrm{~min})$ and $0.5 \mathrm{~mL}$ of supernatant plus $0.5 \mathrm{~mL}$ of internal standard (20 mmol, 4-methylvaleric acid) were transferred into $2 \mathrm{~mL}$ glass tube and kept at $4^{\circ} \mathrm{C}$ pending for analyses. The concentrations of VFA were determined by gas chromatography (Agilent Technologies, USA, Model GC6890) with a flame ionization detector (FID) and fused silica capillary column. Nitrogen was used as carrier gas. Acetate $(20 \mathrm{mmol})$, propionate $(10 \mathrm{mmol})$, Butyrate $(10 \mathrm{mmol})$, isobutyrate $(10 \mathrm{mmol})$, valerate $(10 \mathrm{mmol})$, and isovalerate $(10 \mathrm{mmol})$ were used as standard solution [28].

2.7. DNA Extraction and Quantitative Real-Time PCR. One and half millilitre $(1.5 \mathrm{~mL})$ of rumen fluid sample was used for microbial quantification by real time PCR. DNA was extracted from rumen fluid using the QIA amp DNA Stool Mini Kit (Qiagen Inc., Valencia, CA, USA) according to the manufacturer's protocol. The extracted DNA was stored at $-20^{\circ} \mathrm{C}$ until used. The DNA for each group of microorganisms was amplified from the DNA extract of rumen fluid using specific primers as indicated in Table 1. The PCR reaction was performed on a total volume of $100 \mu \mathrm{L}$ using the i-Taq TM DNA Polymer ASE kit (INTRON Biotechnology, Korea). Each reaction included $2.5 \mu \mathrm{L}$ i-Taq DNA Polymer ASE $(5 \mathrm{U} / \mu \mathrm{L}), 10 \mu \mathrm{L}$ PCR buffer, $5 \mu \mathrm{L}$ of each Primer (10 pM), $10 \mu \mathrm{L}$ dNTP $(2.5 \mu \mathrm{M}$ each), $5 \mu \mathrm{L}$ of DNA sample of rumen fluid, and $62.5 \mu \mathrm{L} \mathrm{H}_{2} \mathrm{O}$. Purified PCR products were cloned into the pCR 2.1 TOPO vector using PCR 2.1 TOPO TA Cloning Kit (Invitrogen Ltd., USA) according to the protocol of manufacturer. Produced plasmid DNAs were sequenced for confirmation. Plasmid DNA from each group of microorganisms was used for preparation of standard curve and the purity and concentration of Plasmid DNA in each sample were measured using a spectrophotometer and the number of copies of a template DNA per $\mathrm{mL}$ of elution buffer was calculated using the formula that is available online (http://www.uri.edu/research/gsc/resources/cndna.html):

number of copeis

$$
=\frac{\text { Amount of DNA }(\mu \mathrm{g} / \mathrm{mL}) \times 6.022 \times 10^{23}}{\text { Length }(\mathrm{bp}) \times 10^{9} \times 650} \text {. }
$$

Standard curves were constructed using serial dilution of plasmid DNA of each microbial group.

Primers used to quantify the population of different groups of microorganisms are shown in Table 1. Real-time PCR was performed with the BioRad CFX96 Touch (BioRad, USA) using optical grade plates. The PCR reaction was performed on a total volume of $25 \mu \mathrm{L}$ using the iQTMSYBR Green Supermix (BioRad, USA). Each reaction included $12.5 \mu \mathrm{L}$ SYBR Green Supermix, $1 \mu \mathrm{L}$ of each Primer, $1 \mu \mathrm{L}$ of DNA samples, and $9.5 \mu \mathrm{L} \mathrm{H}_{2} \mathrm{O}$.

The following reaction conditions were applied to each well: an initial 5-min incubation at $94^{\circ} \mathrm{C}$; and 40 cycles of denaturation at $94^{\circ} \mathrm{C}$ for $20 \mathrm{~s}$, annealing (temperatures for different primers described in Table 1) for $30 \mathrm{~s}$, and extending at $72^{\circ} \mathrm{C}$ for $20 \mathrm{~s}$. To confirm the specificity of amplification, melting curve analysis was carried out after the last cycle of each amplification and PCR products were verified on a $2 \%(\mathrm{~W} / \mathrm{V})$ agarose gel that runs for $40 \mathrm{~min}$ at $80 \mathrm{~V}$. The expected sizes of amplified fragments were presented in 


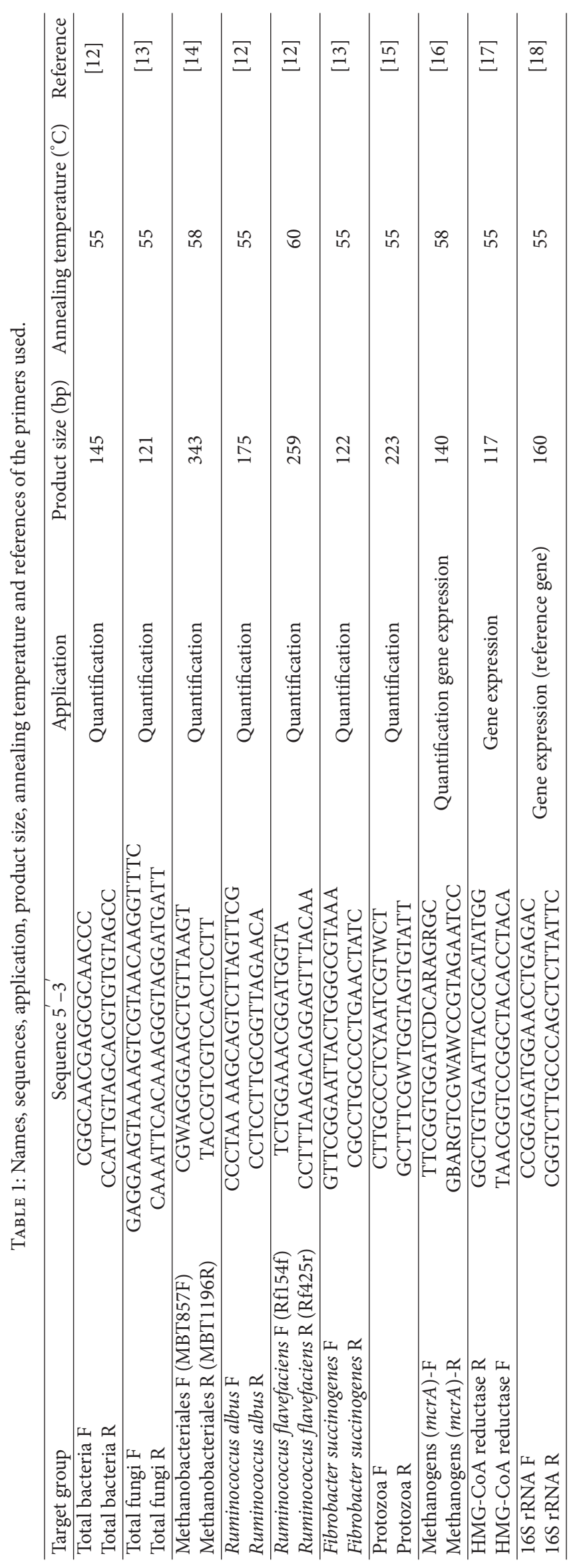


Table 1. The amplification efficiency was calculated using the equation $E=\left(10^{-1 / \text { slope }}-1\right) \times 100 \%$, and only the data generated from reactions with efficiency between 90 and $110 \%$ were used for further analysis [29].

2.8. RNA Extraction and Gene Expression. At the end of $48 \mathrm{~h}$ in vitro gas production, $1.5 \mathrm{~mL}$ of rumen liquor was collected and stored in $-80^{\circ} \mathrm{C}$ for microbial RNA extraction. RNA was extracted using Ribo Pure Bacteria RNA Isolation kit (AMBION, Austin, TX, USA, AM1925) according to the manufacturer's protocol. Two-step method was used for determination of relative gene expression. RNA samples were reverse transcribed into First-strand cDNA using FirstStrand cDNA synthesis Kit according to the manufacturer's instructions (Maxime RT-PCR Kit, iNtRON). In the next step, real-time PCR was performed with the BioRad CFX96 Touch (BioRad, USA) using optical grade plates. The PCR reaction was performed on a total volume of $25 \mu \mathrm{L}$ using the iQTMSYBR Green Supermix (BioRad, USA). Each reaction included $12.5 \mu \mathrm{L}$ SYBR Green Supermix, $1 \mu \mathrm{L}$ of each Primer, $1 \mu \mathrm{L}$ of cDNA samples, and $9.5 \mu \mathrm{L} \mathrm{H}_{2} \mathrm{O}$. The primer that was used for amplification of methyl coenzyme- $\mathrm{M}$ reductase subunit A $(m c r A)$ gene in the terminal step of the methanogenesis pathway and HMG-CoA Reductase $(h m g)$ gene is shown in Table 1. 16S rRNA was used as reference gene [18]. The $2^{-\Delta \Delta \mathrm{Ct}}$ method was used for expression analysis of the $m c r A$ and $h m g$ genes [30].

2.9. Statistical Analysis. All experiments were conducted with 6 replicates per treatment. Individual culture syringes were considered as experimental units. In the first experiment (effect of FRSE on rumen microorganisms), data were analyzed as a completely randomized design (CRD) using the general linear model (GLM) procedure of SAS 9.2 [31]. All multiple comparisons among means were performed using Duncan's new multiple-range test $(P<0.05)$. In the second experiment (effect of FRS and RS on rumen microoorganisms), $t$-test method of SAS 9.2 [31] was used for statistical analysis.

\section{Results}

3.1. Lovastatin Production. Lovastatin productions by A. terreus using rice straw as substrate in SSF at different incubation times as quantified by HPLC are shown in Figure 1 as we previously reported [24]. Since maximum production of the lovastatin was detected after $8 \mathrm{~d}$ of fermentation with maximum production of $260.8 \mathrm{mg} / \mathrm{kg} \mathrm{DM}$, a sample from the above treatment was selected to examine the effect of FRS containing lovastatin on rumen microorganisms. On the other hand, concentration of lovastatin in FRSE was $97 \mathrm{mg} / \mathrm{g}$ DM.

3.2. Lignocellulose Reduction. The abilities of A. terreus to reduce lignocelluloses content of rice straw are shown in Figure 2. SSF significantly $(P<0.01)$ reduces cellulose and hemicelluloses contents but not lignin (ADL) of the RS. Hemicellulose was reduced by $32.68 \%$, (from 25.62 to

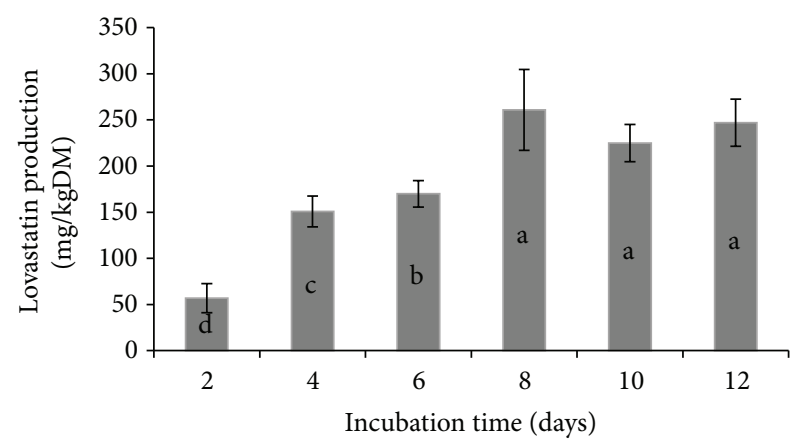

FIgURE 1: Lovastatin production by $A$. terreus in solid-state fermentation at different incubation times. a, b, c, and d: indicating means that differed significantly [24].

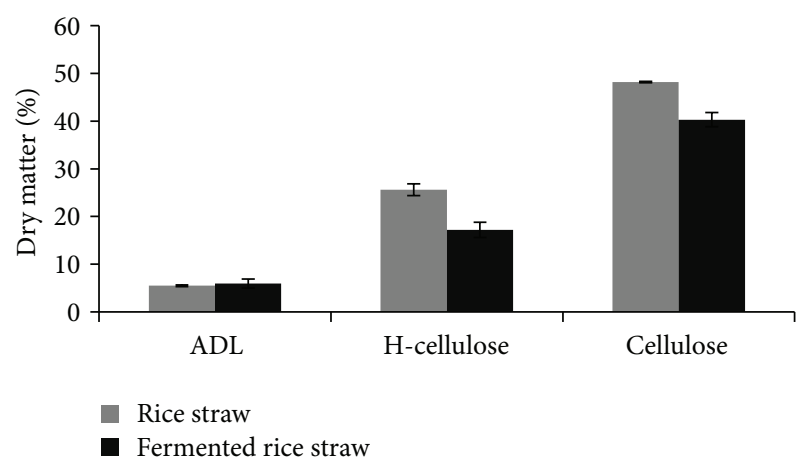

FIGURE 2: Effect of biological treatment using A. terreus on lignocellulose composition of rice straw (\% dry matter).

$17.20 \%$ ) while cellulose was reduced by $16.32 \%$ (from 48.17 to $40.31 \%$ ) after $8 \mathrm{~d}$ of fermentation.

Transmission electron micrograph (Figure 3) clearly shows the ability of $A$. terreus to break down the lignocellulose of FRS and thus increased its surface areas for ruminal microorganisms, specially cellulolytic bacteria to adhere and degradate them further.

3.3. Effect of FRSE on Rumen Microorganisms. One of the main objectives of this study was to provide evidence that fermentation, besides degrading the lignocellulose content of the FRS (which containing lovastatin), also reduces ruminal methanogenesis. To achieve the above-mentioned objective, lovastatin from FRS was extracted using methanol and its quantity in the crude extract was determined using HPLC. The lovastatin content of the FRSE was $97 \mathrm{mg} / \mathrm{g}$ dry matter of the crude extract.

The FRSE containing lovastatin at 10 and $20 \mathrm{mg}$ levels significantly reduced the total in vitro gas production by mixed rumen microorganisms after $12 \mathrm{~h}(P<0.05), 24$, 36 , and $48 \mathrm{~h}(P<0.01)$ incubation (Table 2$)$. Total gas production after $48 \mathrm{~h}$ incubation was $74.4 \mathrm{~mL}$ for the control and 71 and $66.6 \mathrm{~mL}$ for 10 and $20 \mathrm{mg}$ of FRSE, respectively. The two levels of FRSE also significantly $(P<0.01)$ reduced total $\mathrm{CH}_{4}$ production by rumen methanogenic Archaea after $48 \mathrm{~h}$ incubation $(723.21,616.62$, and $521.65 \mu \mathrm{M}$ for 
TABLE 2: Effect of fermented rice extract (FRSE) on in vitro gas, methane and hydrogen production and rate of gas production.

\begin{tabular}{|c|c|c|c|c|}
\hline Gas production $(\mathrm{mL})$ & Ethanol (control) & FRSE (10 mg) & FRSE (20 mg) & Significant \\
\hline $2 \mathrm{~h}$ & $2.7 \pm 0.4$ & $2.8 \pm 0.5$ & $3.0 \pm 0.3$ & NS \\
\hline $4 \mathrm{~h}$ & $4.7 \pm 0.7$ & $4.9 \pm 0.8$ & $5.3 \pm 0.4$ & NS \\
\hline $8 \mathrm{~h}$ & $6.9 \pm 0.9$ & $6.8 \pm 1.1$ & $7.3 \pm 0.5$ & NS \\
\hline $12 \mathrm{~h}$ & $12.8 \pm 1.0^{\mathrm{a}}$ & $11.0 \pm 1.3^{\mathrm{b}}$ & $11.2 \pm 0.3^{\mathrm{b}}$ & $*$ \\
\hline $24 \mathrm{~h}$ & $38.6 \pm 2.1^{\mathrm{a}}$ & $31.8 \pm 1.4^{\mathrm{b}}$ & $28.7 \pm 0.9^{c}$ & $* *$ \\
\hline $36 \mathrm{~h}$ & $58.3 \pm 2.1^{\mathrm{a}}$ & $53.0 \pm 1.4^{\mathrm{b}}$ & $46.5 \pm 2.8^{\mathrm{c}}$ & $* *$ \\
\hline $48 \mathrm{~h}$ & $74.4 \pm 2.1^{\mathrm{a}}$ & $71.0 \pm 2.0^{\mathrm{b}}$ & $66.6 \pm 1.3^{c}$ & ** \\
\hline \multicolumn{5}{|l|}{ Methane production } \\
\hline$\%$ & $21.76 \pm 1.16^{\mathrm{a}}$ & $19.47 \pm 1.50^{\mathrm{b}}$ & $17.55 \pm 0.80^{\mathrm{c}}$ & $* *$ \\
\hline$\mu \mathrm{M}$ & $723.21 \pm 52.56^{\mathrm{a}}$ & $616.62 \pm 41.38^{\mathrm{b}}$ & $521.65 \pm 25.21^{\mathrm{c}}$ & $* *$ \\
\hline \multicolumn{5}{|l|}{ Hydrogen production } \\
\hline$\%$ & $5.65 \pm 0.88$ & $5.33 \pm 0.80$ & $4.79 \pm 1.21$ & NS \\
\hline$\mu \mathrm{M}$ & $187.22 \pm 9.189$ & $153.46 \pm 11.255$ & $154.72 \pm 12.996$ & NS \\
\hline Rate of GP $(\mathrm{mL} / \mathrm{h})$ & $1.55 \pm 0.04^{\mathrm{a}}$ & $1.48 \pm 0.04^{\mathrm{b}}$ & $1.39 \pm 0.03^{\mathrm{c}}$ & $* *$ \\
\hline Rate of $\mathrm{CH}_{4}(\mathrm{~mL} / \mathrm{h})$ & $0.34 \pm 0.02^{\mathrm{a}}$ & $0.29 \pm 0.02^{\mathrm{b}}$ & $0.24 \pm 0.01^{c}$ & $* *$ \\
\hline $\mathrm{CH}_{4} /$ total & $0.22 \pm 0.012^{\mathrm{a}}$ & $0.20 \pm 0.015^{\mathrm{b}}$ & $0.18 \pm 0.008^{\mathrm{c}}$ & $* *$ \\
\hline
\end{tabular}

Data are mean \pm SD.

NS: not significantly different.

* Significantly different at $5 \%$ level.

** Significantly different at $1 \%$ level.

$\mathrm{a}, \mathrm{b}$, and $\mathrm{c}$ : indicating means within row differed significantly.

TABLE 3: Effect of fermented rice straw (FRSE) on VFA production (mmol), $\mathrm{pH}$ and IVDMD (\%).

\begin{tabular}{|c|c|c|c|c|}
\hline & Ethanol (control) & FRSE (10 mg) & FRSE (20 mg) & Significant \\
\hline Acetate & $36.09 \pm 0.43^{\mathrm{b}}$ & $38.67 \pm 1.34^{\mathrm{a}}$ & $38.65 \pm 0.94^{\mathrm{a}}$ & $* *$ \\
\hline Propionate & $13.98 \pm 0.42^{\mathrm{ab}}$ & $14.19 \pm 0.47^{\mathrm{a}}$ & $13.55 \pm 0.29^{b}$ & $*$ \\
\hline Isobutyrate & $0.75 \pm 0.01^{\mathrm{a}}$ & $0.72 \pm 0.01^{\mathrm{b}}$ & $0.72 \pm 0.01^{b}$ & $* *$ \\
\hline Butyrate & $3.78 \pm 0.12^{\mathrm{b}}$ & $4.09 \pm 0.07^{\mathrm{a}}$ & $4.20 \pm 0.06^{\mathrm{a}}$ & $* *$ \\
\hline Isovalerate & $1.61 \pm 0.04^{\mathrm{a}}$ & $1.51 \pm 0.03^{\mathrm{b}}$ & $1.49 \pm 0.03^{\mathrm{b}}$ & $* *$ \\
\hline Valerate & $0.49 \pm 0.01$ & $0.51 \pm 0.01$ & $0.52 \pm 0.01$ & $* *$ \\
\hline Total & $56.70 \pm 0.69^{\mathrm{b}}$ & $59.69 \pm 1.62^{\mathrm{a}}$ & $59.12 \pm 1.12^{\mathrm{a}}$ & $* *$ \\
\hline $\mathrm{A} / \mathrm{P}$ & $2.58 \pm 0.09^{c}$ & $2.73 \pm 0.10^{\mathrm{b}}$ & $2.85 \pm 0.07^{\mathrm{a}}$ & $* *$ \\
\hline GP/VFA & $1.31 \pm 0.045^{\mathrm{a}}$ & $1.19 \pm 0.028^{\mathrm{b}}$ & $1.13 \pm 0.026^{\mathrm{c}}$ & $* *$ \\
\hline $\mathrm{CH}_{4} / \mathrm{VFA}$ & $0.14 \pm 0.011^{\mathrm{a}}$ & $0.12 \pm 0.010^{\mathrm{b}}$ & $0.10 \pm 0.005^{\mathrm{c}}$ & $* *$ \\
\hline $\mathrm{pH}$ & $6.95 \pm 0.01$ & $6.97 \pm 0.01$ & $6.94 \pm 0.03$ & NS \\
\hline IVDMD & $46.81 \pm 0.84$ & $46.36 \pm 1.33$ & $46.62 \pm 1.47$ & NS \\
\hline
\end{tabular}

Data are mean \pm SD.

NS: not significantly different.

${ }^{*}$ Significantly different at $5 \%$ level.

${ }^{* *}$ Significantly different at $1 \%$ level.

$a, b$, and c: indicating means within row differed significantly.

the control, $10 \mathrm{mg}$, and $20 \mathrm{mg}$ FRSE, resp.). The FRSE also reduced $(P<0.01)$ the rate of gas and $\mathrm{CH}_{4}$ production $(\mathrm{mL} / \mathrm{h})$ as well as the ratio of $\mathrm{CH}_{4}$ to total gas (Table 2).

The effects of FRSE on VFA production by rumen microorganisms are shown in Table 3. The FRSE treatments increased VFA, particularly acetate production $(P<0.01)$. However, it has no effect $(P>0.05)$ on IVDMD of the rice straw and $\mathrm{pH}$ of the rumen fluid after $48 \mathrm{~h}$ incubation. Rates of gas and $\mathrm{CH}_{4}$ productions per unit of VFA produced in the FRSE treatments were lower $(P<0.01)$ than those for the control.

3.4. Effect of FRSE on Microbial Population. The effect of FRSE on rumen microbial population is presented in Table 4 . Population of total methanogens in the treatments containing FRSE was lower $(P<0.01)$ than the control. FRSE also 
TABLE 4: Effect of fermented rice straw extract (FRSE) on microbial population in the rumen liquid (cell/mL).

\begin{tabular}{|c|c|c|c|c|}
\hline Microorganisms & Ethanol (control) & FRSE (10 mg) & FRSE (20 mg) & Significant \\
\hline Total methanogens $\left(\times 10^{7}\right)$ & $1.30 \pm 0.172^{\mathrm{a}}$ & $0.98 \pm 0.121^{\mathrm{b}}$ & $0.97 \pm 0.248^{\mathrm{b}}$ & $*$ \\
\hline Methanobacteriales $\left(\times 10^{6}\right)$ & $2.65 \pm 0.215^{\mathrm{a}}$ & $2.20 \pm 0.177^{\mathrm{b}}$ & $2.25 \pm 0.240^{\mathrm{b}}$ & * \\
\hline Anaerobic fungi $\left(\times 10^{6}\right)$ & $2.69 \pm 0.271^{\mathrm{a}}$ & $1.78 \pm 0.922^{\mathrm{b}}$ & $0.47 \pm 0.258^{\mathcal{c}}$ & ** \\
\hline Total bacteria $\left(\times 10^{11}\right)$ & $2.55 \pm 0.434^{\mathrm{a}}$ & $2.38 \pm 0.329^{\mathrm{a}}$ & $1.93 \pm 0.237^{\mathrm{b}}$ & $*$ \\
\hline Ruminococcus albus $\left(\times 10^{8}\right)$ & $6.08 \pm 0.966^{\mathrm{b}}$ & $10.46 \pm 0.668^{\mathrm{a}}$ & $9.98 \pm 1.139^{\mathrm{a}}$ & $* *$ \\
\hline Fibrobacter succinogenes $\left(\times 10^{7}\right)$ & $2.88 \pm 0.742^{\mathrm{b}}$ & $6.87 \pm 1.840^{\mathrm{a}}$ & $8.16 \pm 0.686^{\mathrm{a}}$ & $* *$ \\
\hline Ruminococcus flavefaciens $\left(\times 10^{6}\right)$ & $1.05 \pm 0.375^{\mathrm{b}}$ & $1.46 \pm 0.360^{\mathrm{a}}$ & $1.31 \pm 0.226^{\mathrm{a}}$ & $*$ \\
\hline Protozoa $\left(\times 10^{5}\right)$ & $4.12 \pm 0.893$ & $4.65 \pm 0.663$ & $4.12 \pm 0.692$ & NS \\
\hline
\end{tabular}

Data are mean \pm SD.

NS: not significantly different.

* Significantly different at $5 \%$ level.

** Significantly different at $1 \%$ level.

$\mathrm{a}, \mathrm{b}$, and $\mathrm{c}$ : indicating means within row differed significantly.

TABLE 5: Comparative in vitro gas, methane and hydrogen productions by rumen microorganisms and rate of gas production between rice straw (RS) and fermented rice straw (FRS).

\begin{tabular}{|c|c|c|c|}
\hline Gas production $(\mathrm{mL})$ & RS & FRS & Significant \\
\hline $2 \mathrm{~h}$ & $1.8 \pm 0.3$ & $3.2 \pm 0.3$ & ** \\
\hline $4 \mathrm{~h}$ & $3.8 \pm 0.8$ & $5.5 \pm 0.4$ & $* *$ \\
\hline $8 \mathrm{~h}$ & $5.8 \pm 1.1$ & $7.4 \pm 0.5$ & $* *$ \\
\hline $12 \mathrm{~h}$ & $10.8 \pm 1.7$ & $10.5 \pm 0.7$ & NS \\
\hline $24 \mathrm{~h}$ & $31.9 \pm 2.4$ & $22.6 \pm 2.1$ & $* *$ \\
\hline $36 \mathrm{~h}$ & $47.0 \pm 2.4$ & $35.9 \pm 2.9$ & $* *$ \\
\hline $48 \mathrm{~h}$ & $55.9 \pm 1.0$ & $47.0 \pm 2.2$ & $* *$ \\
\hline \multicolumn{4}{|l|}{ Methane production } \\
\hline$\%$ & $11.26 \pm 0.70$ & $10.25 \pm 0.51$ & * \\
\hline$\mu \mathrm{M}$ & $28.15 \pm 17.058$ & $214.78 \pm 9.087$ & $* *$ \\
\hline \multicolumn{4}{|l|}{$\mathrm{H}_{2}$ production } \\
\hline$\%$ & $5.71 \pm 0.36$ & $5.15 \pm 0.42$ & NS \\
\hline$\mu \mathrm{M}$ & $141.41 \pm 6.73$ & $105.8 \pm 7.77$ & $*$ \\
\hline Rate of GP (mL/h) & $1.16 \pm 0.020$ & $0.979 \pm 0.047$ & $* *$ \\
\hline Rate of $\mathrm{CH}_{4}(\mathrm{~mL} / \mathrm{h})$ & $0.13 \pm 0.008$ & $0.100 \pm 0.004$ & $* *$ \\
\hline $\mathrm{CH}_{4} /$ total & $0.11 \pm 0.007$ & $0.102 \pm 0.005$ & $*$ \\
\hline
\end{tabular}

Data are means \pm SD

NS: not significantly different.

* Significantly different at 5\% level.

** Significantly different at $1 \%$ level.

reduced $(P<0.05)$ the population of Methanobacteriales species (the dominant group of methanogenic Archaea in the rumen) and anaerobic fungi $(P<0.01)$ in the rumen liquid. Although treatment containing $20 \mathrm{mg}$ FRSE reduced $(P<0.05)$ the population of total bacteria, the population of cellulolytic bacteria including Ruminococcus albus, Fibrobacter succinogenes $(P<0.01)$, and Ruminococcus flavefaciens $(P<0.05)$ that play important roles on the degradation of lignocellulosic materials increased. FRSE has no significant effect on population of Protozoa $(P>0.05)$.

3.5. Effect of FRS on Rumen Microorganisms. Total gas production after 2,4 , and $8 \mathrm{~h}$ incubation was higher $(P<0.01)$ in the FRS treatments but thereafter the corresponding values were lower for FRS (Table 5). FRS also reduced $(P<0.01)$ the total $\mathrm{CH}_{4}$ production, rates of total gas, and $\mathrm{CH}_{4}$ production by rumen microorganisms after $48 \mathrm{~h}$ incubation. The ratio of $\mathrm{CH}_{4}$ to total gas in the treatment containing FRS was lower $(P<0.05)$ than non-fermented RS. In addition, quantity of hydrogen $\left(\mathrm{H}_{2}\right)$ in the FRS was lower $(P<0.05)$ than RS treatment.

Effects of FRS on VFA production by rumen microorganisms are presented in Table 6. Although FRS has no effect on total VFA production $(P>0.05)$ it increased IVDMD, ratio of total gas: VFA, and $\mathrm{CH}_{4}$ : VFA $(P<0.01)$.

Similar to the FRSE, FRS reduced the population of total methanogens, Methanobacteriales $(P<0.05)$, total fungi, total bacteria, and Fibrobacter succinogenes $(P<0.01)$, 
TABLE 6: Effect of rice straw (RS) and fermented rice straw (FRS) on VFA production (mmol), pH and IVDMD (\%).

\begin{tabular}{lccc}
\hline & RS & FRS & Significant \\
\hline Acetate & $37.49 \pm 2.22$ & $34.92 \pm 2.51$ & NS \\
Propionate & $14.44 \pm 0.75$ & $13.01 \pm 0.83$ & $*$ \\
Isobutyrate & $0.77 \pm 0.04$ & $0.76 \pm 0.03$ & NS \\
Butyrate & $3.80 \pm 0.14$ & $3.77 \pm 0.16$ & NS \\
Isovalerate & $1.66 \pm 0.08$ & $1.71 \pm 0.08$ & NS \\
Valerate & $0.49 \pm 0.02$ & $0.48 \pm 0.02$ & NS \\
Total & $58.65 \pm 3.09$ & $54.65 \pm 3.55$ & NS \\
A/P & $2.60 \pm 0.09$ & $2.68 \pm 0.08$ & NS \\
GP/VFA & $0.96 \pm 0.059$ & $0.86 \pm 0.039$ & $* *$ \\
CH $/$ VFA & $0.05 \pm 0.004$ & $0.04 \pm 0.002$ & $* .95 \pm 0.04$ \\
pH & $6.87 \pm 0.03$ & $49.01 \pm 0.79$ & $*$ \\
IVDMD & $45.81 \pm 1.48$ & & $*$ \\
\hline
\end{tabular}

Data are mean \pm SD.

NS: not significantly different.

* Significantly different at $5 \%$ level.

** Significantly different at $1 \%$ level.

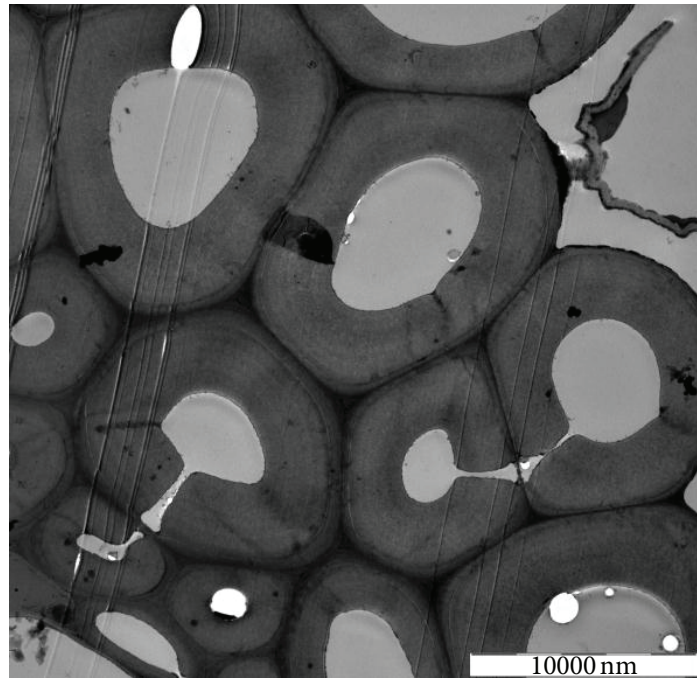

(a)

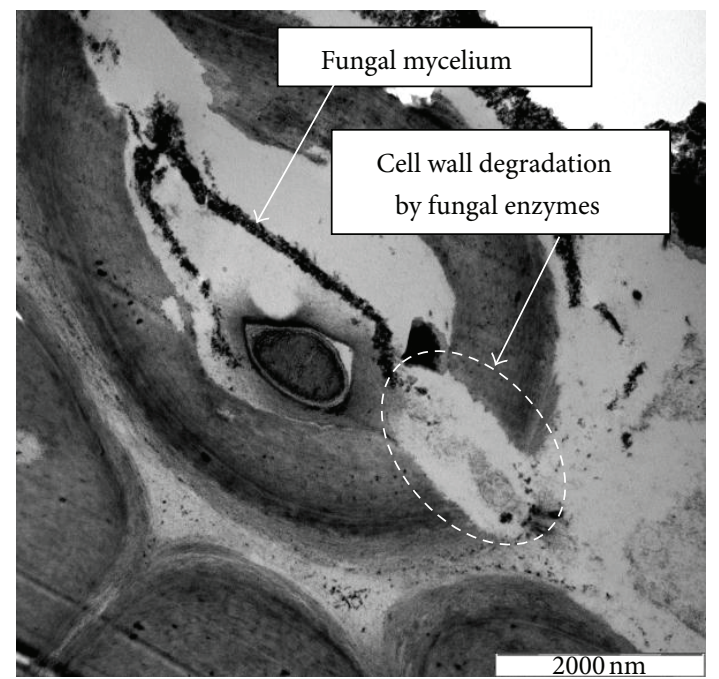

(b)

FiguRE 3: Effect of A. terreus on cell wall structure of rice straw; (a) before and (b) after fermentation.

but increased the population of Ruminococcus albus $(P<$ 0.01 ) (Table 7). FRS has no effect on the population of Ruminococcus flavefaciens and protozoa $(P>0.05)$.

3.6. Expression of mcrA and hmg Genes. The effects of FRSE and FRS on expression of mcrA and hmg genes of methanogens bacteria in the rumen liquid samples are presented in Figure 4. After $48 \mathrm{~h}$ incubation, both FRSE (Figure 4(a)) and FRS (Figure 4(b)) significantly increased the expression of $h m g$ gene compared to the control $(P<0.01)$ but had no effect on $m c r A$ gene.

\section{Discussion}

4.1. Lovastatin Production and Lignocellulose Reduction. Solid-state fermentation is the growth of microorganisms on moist solid materials in the absence or near absence of free water [32] and the United State Food and Administration (USFAD) has approved its use for commercial production of clinical drugs, including lovastatin from fungi [33]. Although pure lovastatin has been shown to significantly suppress methanogenesis [34], it is too expensive to be used as an additive in ruminant diets for $\mathrm{CH}_{4}$ mitigation. We [24] have previously produced lovastatin by fermenting rice straw, an agrobiomass, using $A$. terreus. The optimal concentration of lovastatin obtained after 8 days fermentation using the above procedure was approximately $261 \mathrm{mg} / \mathrm{g}$ $\mathrm{DM}$, which is much lower than the 4 to $6 \mathrm{mg}$ lovastatin produced from per $\mathrm{g}$ of energy-rich rice grain as substrate [35]. However, based on results of the fiber reduction (Table 2) and effectiveness of the suppression of $\mathrm{CH}_{4}$ emission (Tables 2 and 4), the lovastatin content in the FRS is 
TABLE 7: Effect of rice straw (RS) and fermented rice straw (FRS) on microbial population in the rumen liquid (cell/mL).

\begin{tabular}{|c|c|c|c|}
\hline \multirow{2}{*}{ Microorganisms } & \multicolumn{2}{|c|}{ Treatment } & \multirow{2}{*}{ Significant } \\
\hline & RS & FRS & \\
\hline Total methanogens $\left(\times 10^{6}\right)$ & $3.089 \pm 0.553$ & $2.34 \pm 0.125$ & * \\
\hline Methanobacteriales $\left(\times 10^{6}\right)$ & $1.47 \pm 0.154$ & $0.96 \pm 0.177$ & * \\
\hline Anaerobic fungi $\left(\times 10^{6}\right)$ & $10.79 \pm 2.506$ & $2.14 \pm 0.666$ & * \\
\hline Total bacteria $\left(\times 10^{11}\right)$ & $2.86 \pm 0.349$ & $2.39 \pm 0.276$ & $* *$ \\
\hline Ruminococcus albus $\left(\times 10^{8}\right)$ & $2.29 \pm 0.126$ & $5.40 \pm 0.353$ & $* *$ \\
\hline Fibrobacter succinogenes $\left(\times 10^{7}\right)$ & $4.51 \pm 0.922$ & $1.82 \pm 0.255$ & $* *$ \\
\hline Ruminococcus flavefaciens $\left(\times 10^{6}\right)$ & $0.93 \pm 0.107$ & $0.87 \pm 0.110$ & NS \\
\hline Protozoa $\left(\times 10^{5}\right)$ & $8.50 \pm 1.012$ & $9.96 \pm 1.407$ & NS \\
\hline
\end{tabular}

Data are mean \pm SD.

NS: not significantly different.

* Significantly different at $5 \%$ level.

** Significantly different at $1 \%$ level.

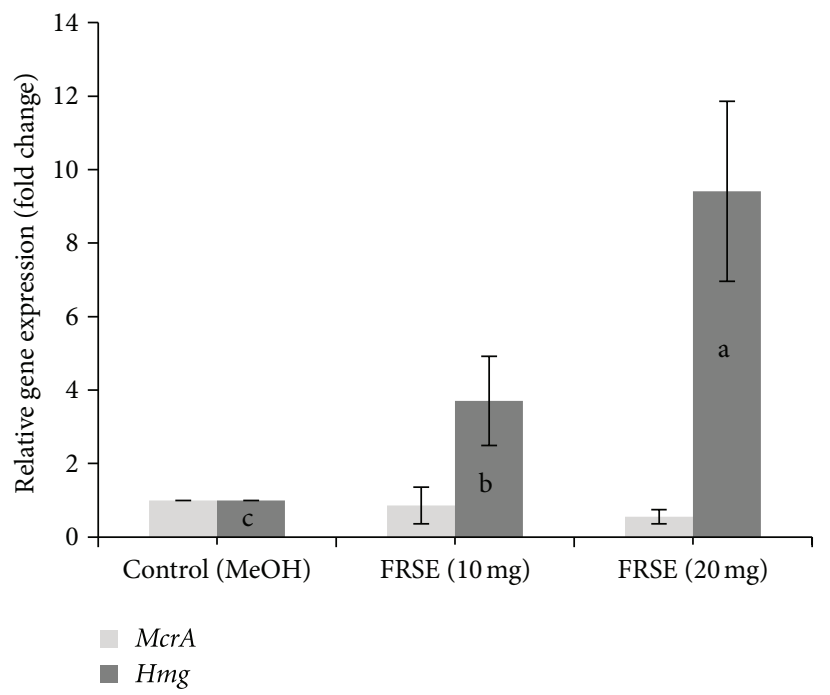

(a)

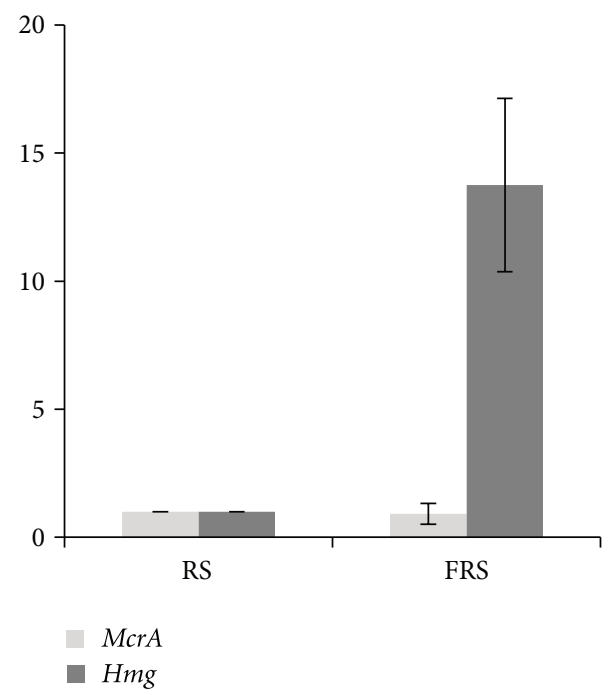

(b)

FIGURE 4: Effect of fermented rice straw extract (FRSE) (Figure 4(a)) and fermented rice straw (FRS) (Figure 4(b)) on expression of $m c r A$ and $h m g$ genes in the rumen liquid sample. Treatment has no significant effect on expression of $m c r A$ gene $(P>0.05)$ and significantly increased the expression of $h m g$ gene $(P<0.01) . \mathrm{a}, \mathrm{b}$, and $\mathrm{c}$ : indicating differences among means between samples.

believed to be sufficient for the intended purpose in this study.

The ability of $A$. terreus to produce cellulolytic enzymes has been well documented [36-39] with xylanase as the main enzyme in SSF by A. terreus [37]. The higher reduction of hemicelluloses (from 25.62 to $14.94 \%$ ) which constitute primarily xylan, compared to cellulose (from 48.17 to $38.36 \%$ ) over the control in our study, reaffirmed the above. High lignocellulose content in most agro-biomass, including RS, is the main constraint for its widespread use as ruminant feed. Biological treatment has been suggested to be able to improve the quality of these materials [40] as the polysaccharides including cellulose and hemicelluloses are converted into monomers such as glucose and xylose, and the latter are used for production of more fungal cell mass. Therefore, the reduction in the lignocelluloses content in the FRS in this study is an indication of an improvement of the fermented material. The ability of $A$. terreus to use the lignocelluloses materials for growth and to increase it cell mass on the surface of rice straw and to breakdown its lignocellulosic structure of the FRS is clearly shown in Figures 2 and 3, respectively. A previous report [40] showed that fermented agrobiomass containing fungal cell mass has higher digestibility compared to non-fermented materials.

4.2. Effect of FRS and FRSE on Rumen Microbiota. Rumen contains an array of microorganisms playing their respective roles in the degradation of fiber component of feed materials [41-43]. Volatile fatty acids production from the rumen microbial activity and the subsequent microbial mass produced can be digested and absorbed by the host animals for growth and other functions [41]. The above are the beneficial effect of ruminal microbial activity. In contrast, rumen methanogenic Archaea are microorganisms that result in 
losses of dietary energy by converting $\mathrm{H}_{2}$, carbon, and VFA (mainly acetate) into $\mathrm{CH}_{4}$ in the process of methanogenesis. To overcome this negative nutritional effect on the host animals, together with the role of $\mathrm{CH}_{4}$ as a greenhouse gas on global warming and climatic change, many $\mathrm{CH}_{4}$ mitigation agents have been tested to inhibit methanogenesis in the rumen. However, most of the existing methodologies are not applicable under farm conditions, primarily because the inhibitors are also suppressing activity of cellulolytic bacteria and thus reduced fiber digestion.

There is a close similarity in cholesterol biosynthesis in the eukaryotic cells and cell membrane biosynthesis in the Archaea. HMG-CoA reductase is a key enzyme that catalyses the production of mevalonic acid from HMG-CoA in the eukaryotes and Archaea, and statins are the inhibitor of this enzyme. This enzyme is essential for production of Geranylgeranyl isopentenyl-5-pyrophosphate for synthesis of the branched isoprene side chains in the Archaeal phospholipids. The main difference between Archaea and other microorganisms is the structure of cell membrane; the lipid side of phospholipid in the Archaea is branched isoprene side chains but the lipid of phospholipid in other microorganisms is fatty acid [22]. Methanogenic bacteria are the main group of Archaea in the rumen [23]; thus, they will be the key microorganisms (except for fungi, see later discussion) affected by any HMG-CoA reductase inhibitors within the rumen. Our results support the above hypothesis. Both the lovastatin-rich FRSE and FRS reduced the population of methanogenic Archaea (Tables 4 and 7) and $\mathrm{CH}_{4}$ production in the rumen fluid cultures (Tables 2 and 5). There was a decrease in the population of total bacteria but the population of Ruminococcus albus, one of the most important cellulolytic bacteria, was significantly increased in both the FRSE and FRS treatments compared to the control (Tables 4 and 7). Although FRSE significantly increased VFA production (Table 3) compared to the control, similar increment was not shown when FRS was used (Table 6). The significant reduction in the total gas and $\mathrm{CH}_{4}$ productions (Table 5) without affecting the VFA production is an indication that lovastatin could suppress $\mathrm{CH}_{4}$ without negatively affecting microbial degradation efficiency in the FRS rumen fluid. In both, the FRSE and FRS experiments, the ratio of total gas/VFA and $\mathrm{CH}_{4} /$ VFA was significantly reduced, indicating that the inhibitive effect of lovastatin on $\mathrm{CH}_{4}$ production was absolute and not a relative reduction due to the suppression of the total gas production.

The higher apparent IVDMD and acetate production accompanied by lower gas and $\mathrm{CH}_{4}$ productions and no differences in VFA production in the FRS treatment compared to the control (unfermented rice straw) (Table 6) seems to be difficult to reconcile biologically. One possible explanation to the above phenomenon is because FRS contained higher soluble materials, such as fungal biomass and soluble sugars [40] and part of this material could have escaped the fermentation process and was later hydrolyzed in the pepsin $/ \mathrm{HCl}$ solution treatment during the determination of the apparent IVDMD.

Another possibility for the above phenomenon is alterations of the cellulolytic bacteria and fungi populations in the FRS and FRSE treatments. Our results show that although the population of total bacteria was reduced, $R$. albus, one of the most important cellulolytic bacteria, was significantly increased in the FRS (and FRSE) treatments (Tables 4 and 7). Miller and Wolin [44] reported that in cellulose substrate, $R$. albus produces high quantity of acetate but very little (unquantifiable) amount of gas after $32 \mathrm{~h}$ incubation. We believe that the increased population of the acetate but not gas producing R. albus (more than $10^{8} \mathrm{cell} / \mathrm{mL}$ ), compared to the other two groups of cellulolytic bacteria (F. succinogenes, $10^{7}$ cell $/ \mathrm{mL}$; . floriu, $10^{6}$ cell $/ \mathrm{mL}$ ), is partially responsible for the low production of the total gas and $\mathrm{CH}_{4}$ without affecting IVDMD and VFA production in the FRS treatment.

In addition, both experiments (FRSE and FRS) showed a significant reduction in the population of the anaerobic fungi in the rumen fluid culture (Tables 4 and 7). Both, synthetic and fermented statins have been reported [45-47] to exhibit antifungal activites, including lovastatin on the activity of Zygomycetes and Rhizomucor species under in vitro condition [45]. Since fungi are eukaryotic microorganisms, HMG-CoA reductase is present in them [48]. Therefore, lovastatin has the same inhibitive effect on the HMG-CoA reductase enzyme in fungi as it has in methanogenic Archaea. According to Pearce and Bauchop [49], rumen fungus (Neocallimastix frontalis) produces high quantity of $\mathrm{H}_{2}$ in cellulose substrate (approximately $44 \%$ of the total gas). Similarly, Yarlett et al. [50] reported that pure culture of rumen fungi produced more $\mathrm{H}_{2}$ than in a mixed culture of rumen fungi and methanogenic Archaea. The above information highlights that rumen fungi is an important source of $\mathrm{H}_{2}$ for the rumen methanogenic Archaea. Furthermore, Bernalier et al. [51] reported that rumen fungi (Neocallimastix frontalis, Piromyces communis, and Caecomyces communis) produced 7 to 10 times higher formate than cellulolytic bacteria ( $R$. flavefaciens and F. succinogenes) in the same cellulose substrate. Since $\mathrm{H}_{2}$ and formate are the main substrates for the production of $\mathrm{CH}_{4}$ by methanogens in the rumen, the reduction of the fungi population in the FRS and FRSE treatments could also contribute to the reduction in $\mathrm{CH}_{4}$ production and without causing an accumulation of $\mathrm{H}_{2}$ in the rumen ecosystem.

We would like to propose that the increased $R$. albus (high acetate and low gas producing cellulolytic bacteria), decreased fungi (low acetate and high $\mathrm{H}_{2}$ producers) population as affected by lovastatin, and the increased digestibility of the FRS are the contributing factors to the high IVDMD and acetate production but lower gas and $\mathrm{CH}_{4}$ productions in the FRS treatment.

4.3. Gene Expression. Results of the gene expression studies showed that lovastatin significantly increased the expression of $h m g$ gene but not that of $m c r A$ gene (producer of enzyme in the last step of methanogenesis pathway) (Figure 4). Our finding suggests that the controlling factor for the upward expression of the $h m g$ gene is the concentration of mevalonic acid produced by HMG-CoA and catalyzed by the HMG$\mathrm{CoA}$ reductase. Inhibition of the $\mathrm{HMG}-\mathrm{CoA}$ reductase by lovastatin suppresses mevalonic acid production, and the reduced mevalonic acid concentration signalled to increase the expression of $h m g$ gene and production of higher mRNA 
and enzyme in the rumen methanogens. Enhancement of the relative expression of genes involved in the process of cholestrol biosynthesis by lovastatin was reported previously [52].

\section{Conclusion}

Lovastatin can be produced in SSF using $A$. terreus and rice straw as substrates as we previously reported [24]. The present study showed that $A$. terreus has the potential to break down lignocelluloses, particularly hemicelluloses in the rice straw, and improved the quality of this agro-biomass as ruminant feed. The above suggestion is supported by the higher IVDMD and acetate production, suggesting higher microbial activity in the FRS treatment compared to the untreated rice straw. Lovastatin in the FRS and FRSE significantly reduced $\mathrm{CH}_{4}$ production and methanogens population, indicating that SSF of rice straw using $A$. terreus is an effective method to enhance the quality of this biomass and at the same time provides a practical method to mitigate methanogenesis and thus enteric $\mathrm{CH}_{4}$ production in ruminants. Since lovastatin also has the potential for cholesterol reduction through its inhibitory effect on HMG-CoA reductase and antioxidant activity [53, 54], feeding the fermented rice straw could potentially produce lower cholesterol and high-quality animal products.

\section{Disclosure}

The authors declare that they do not have any conflict of interests with any third party or receiving any financial gain from this study.

\section{Acknowledgment}

This study was supported by the Fundamental Research Grant Scheme (FRGS 1/2010 UPM) of the Department of Higher Education, Malaysia.

\section{References}

[1] IPCC, "Intergovernmental panel on climate change," in Summary for Policymaker of Synthesis Report, R. K. Pachauri and A. Reisinger, Eds., Cambridge, UK, 2007.

[2] P. J. Crutzen, I. Aselmann, and W. Seiler, "Methane production by domestic animals, wild ruminants, other herbivorous fauna, and humans," Tellus B, vol. 38, no. 3-4, pp. 271-284, 1986.

[3] A. R. Moss, "Measuring methane production from ruminants," in Methane: Global Warming and Production by Animals, H. P. S. Makkar and P. E. Vercoe, Eds., p. 105, Chalcombe, Canterbury, UK, 1993.

[4] F. X. Wildenauer, K. H. Blotevogel, and J. Winter, "Effect of monensin and 2-bromoethanesulfonic acid on fatty acid metabolism and methane production from cattle manure," Applied Microbiology and Biotechnology, vol. 19, no. 2, pp. 125-130, 1984.

[5] S. A. Martin, "Manipulation of ruminal fermentation with organic acids: a review," Journal of Animal Science, vol. 76, no. 12, pp. 3123-3132, 1998.
[6] F. Dohme, A. Machmüller, A. Wasserfallen, and M. Kreuzer, "Ruminal methanogenesis as influenced by individual fatty acids supplemented to complete ruminant diets," Letters in Applied Microbiology, vol. 32, no. 1, pp. 47-51, 2001.

[7] S. Y. Lee, S. H. Yang, W. S. Lee, H. S. Kim, D. E. Shin, and J. K. Ha, "Effect of 2-bromoethanesulfonic acid on in vitro fermentation characteristics and methanogen population," AsianAustralasian Journal of Animal Sciences, vol. 22, no. 1, pp. 42-48, 2009.

[8] N. Mohammed, N. Ajisaka, Z. A. Lila et al., "Effect of Japanese horseradish oil on methane production and ruminal fermentation in vitro and in steers," Journal of Animal Science, vol. 82, no. 6, pp. 1839-1846, 2004.

[9] K. Karimi, G. Emtiazi, and M. J. Taherzadeh, "Ethanol production from dilute-acid pretreated rice straw by simultaneous saccharification and fermentation with Mucor indicus, Rhizopus oryzae, and Saccharomyces cerevisiae," Enzyme and Microbial Technology, vol. 40, no. 1, pp. 138-144, 2006.

[10] M. D. Summers and B. Jenkins, Using Rice Straw for Energy Production: Economics, Energetics and Emissions. For the Final Requirements of EBS 216: Energy Systems, 2001.

[11] S. Alborés, M. J. Pianzzola, M. Soubes, and M. P. Cerdeiras, "Biodegradation of agroindustrial wastes by Pleurotus spp for its use as ruminant feed," Electronic Journal of Biotechnology, vol. 9, no. 3, pp. 215-220, 2006.

[12] S. Koike and Y. Kobayashi, "Development and use of competitive PCR assays for the rumen cellulolytic bacteria: Fibrobacter succinogenes, Ruminococcus albus and Ruminococcus flavefaciens," FEMS Microbiology Letters, vol. 204, no. 2, pp. 361-366, 2001.

[13] D. J. Lane, 16S/23S RRNA Sequencing. Nucleic Acid Techniques in Bacterial Systematics, Edited by StackebrandtE \& GoodfellowM, John Wiley \& Sons, New York, NY, USA, 1991.

[14] Y. Yu, C. Lee, J. Kim, and S. Hwang, "Group-specific primer and probe sets to detect methanogenic communities using quantitative real-time polymerase chain reaction," Biotechnology and Bioengineering, vol. 89, no. 6, pp. 670-679, 2005.

[15] J. T. Sylvester, S. K. R. Karnati, Z. Yu, M. Morrison, and J. L. Firkins, "Development of an assay to quantify rumen ciliate protozoal biomass in cows using real-time PCR," Journal of Nutrition, vol. 134, no. 12, pp. 3378-3384, 2004.

[16] S. E. Denman and C. S. McSweeney, "Development of a realtime PCR assay for monitoring anaerobic fungal and cellulolytic bacterial populations within the rumen," FEMS Microbiology Ecology, vol. 58, no. 3, pp. 572-582, 2006.

[17] B. S. Samuel, E. E. Hansen, J. K. Manchester et al., "Genomic and metabolic adaptations of Methanobrevibacter smithii to the human gut," Proceedings of the National Academy of Sciences of the United States of America, vol. 104, no. 25, pp. 10643-10648, 2007.

[18] M. Zhou, E. Hernandez-Sanabria, and L. G. Le, "Assessment of the microbial ecology of ruminal methanogens in cattle with different feed efficiencies," Applied and Environmental Microbiology, vol. 75, no. 20, pp. 6524-6533, 2009.

[19] L. S. T. Lai, C. C. Pan, and B. K. Tzeng, "The influence of medium design on lovastatin production and pellet formation with a high-producing mutant of Aspergillus terreus in submerged cultures," Process Biochemistry, vol. 38, no. 9, pp. 1317-1326, 2003.

[20] A. W. Alberts, "Discovery, biochemistry and biology of lovastatin," American Journal of Cardiology, vol. 62, no. 15, pp. 10-15, 1988. 
[21] Z. Konrad and J. Eichler, "Lipid modification of proteins in Archaea: attachment of a mevalonic acid-based lipid moiety to the surface-layer glycoprotein of Haloferax volcanii follows protein translocation," Biochemical Journal, vol. 366, no. 3, pp. 959-964, 2002.

[22] A. Smit and A. Mushegian, "Biosynthesis of isoprenoids via mevalonate in archaea: the lost pathway," Genome Research, vol. 10, no. 10, pp. 1468-1484, 2000.

[23] M. J. Wolin and T. L. Miller, "Control of rumen methanogenesis by inhibiting the growth and activity of methanogens with hydroxymethylglutaryl-SCoA inhibitors," in Proceedings of the 2nd International Conference on Greenhouse Gases and Animal Agriculture, Elsevier, Zurich, Switzerland, September 2005.

[24] M. F. Jahromi, J. B. Liang, Y. W. Ho, M. Rosfarizan, Y. M. Goh, and P. Sokryazdan, "Lovastatin production by Aspergillus terreus using agro-biomass as substrate in solid state fermentation," Journal of Biomedicine and Biotechnology, vol. 2012, Article ID 196264, 11 pages, 2012.

[25] M. A. Hayat, Principles and Techniques of Electron Microscopy: Biological Applications, vol. 4, Cambridge University Press, 2000.

[26] K. H. Menke and H. Steingass, "Estimation of the energetic feed value obtained from chemical analysis and in vitro gas production using rumen fluid," Animal Research and Development, vol. 28, pp. 7-55, 1988.

[27] J. M. A. Tilley and R. A. Terry, "A two stage technique for the in vitro digestion of forage crops," Grass and Forage Science, vol. 18, no. 2, pp. 104-111, 1963.

[28] E. Erwin, G. Marco, and E. Emery, "Volatile fatty acid analysis of blood and rumen fluid by gas chromatography, Journal of Dairy Science, vol. 44, pp. 1768-1771, 1961.

[29] M. Zhou, Y. H. Chung, K. Beauchemin et al., "Relationship between rumen methanogens and methane production in dairy cows fed diets supplemented with a feed enzyme additive," Journal of Applied Microbiology, vol. 111, no. 5, pp. 1148-1158, 2011.

[30] K. J. Livak and T. D. Schmittgen, "Analysis of relative gene expression data using real-time quantitative PCR and the 2$\Delta \triangle$ CT method," Methods, vol. 25, no. 4, pp. 402-408, 2001.

[31] SAS, "SAS Institute Inc., SAS OnlineDoc 9. 2. SAS Institute Inc., Cary, NC, USA," 2008.

[32] B. K. Lonsane, N. P. Childyal, S. Budiatman, and S. V. Ramakrishna, "Engineering aspects of solid state fermentation," Enzyme and Microbial Technology, vol. 7, no. 6, pp. 258-265, 1985.

[33] S. Suryanarayan, "Current industrial practice in solid state fermentations for secondary metabolite production: the Biocon India experience," Biochemical Engineering Journal, vol. 13, no. 2-3, pp. 189-195, 2003.

[34] T. L. Miller and M. J. Wolin, "Inhibition of growth of methaneproducing bacteria of the ruminant forestomach by hydroxymethylglutaryl SCoA reductase inhibitors," Journal of Dairy Science, vol. 84, no. 6, pp. 1445-1448, 2001.

[35] B. J. Xu, Q. J. Wang, X. Q. Jia, and C. K. Sung, "Enhanced lovastatin production by solid state fermentation of Monascus ruber," Biotechnology and Bioprocess Engineering, vol. 10, no. 1, pp. 78-84, 2005.

[36] G. Emtiazi, N. Naghavi, and A. Bordbar, "Biodegradation of lignocellulosic waste by Aspergillus terreus," Biodegradation, vol. 12, no. 4, pp. 257-261, 2001.

[37] J. Gao, H. Weng, D. Zhu, M. Yuan, F. Guan, and Y. Xi, "Production and characterization of cellulolytic enzymes from the thermoacidophilic fungal Aspergillus terreus M11 under solidstate cultivation of corn stover," Bioresource Technology, vol. 99, no. 16, pp. 7623-7629, 2008.

[38] J. Gao, H. Weng, Y. Xi, D. Zhu, and S. Han, "Purification and characterization of a novel endo- $\beta$-1,4-glucanase from the thermoacidophilic Aspergillus terreus," Biotechnology Letters, vol. 30, no. 2, pp. 323-327, 2008.

[39] M. F. Jahromi, J. B. Liang, M. Rosfarizan, Y. M. Goh, P. Shokryazdan, and Y. W. Ho, "Efficiency of rice straw lignocelluloses degradability by Aspergillus terreus ATCC 74135 in solid state fermentation," African Journal of Biotechnology, vol. 10, no. 21, pp. 4428-4435, 2011.

[40] D. Jalč, F. Nerud, and P. Siroka, "The effectiveness of biological treatment of wheat straw by white-rot fungi," Folia Microbiologica, vol. 43, no. 6, pp. 687-689, 1998.

[41] J. D. Brooker, D. K. Lum, S. Miller, I. Skene, and L. O'Donovan, "Rumen microorganisms as providers of high quality protein," Livestock Research For Rural Development, vol. 6, no. 3, 1995.

[42] M. X. T. Alvarez, Molecular ecology of rumen bacterial populations in steers fed molasses diets [Ph.D. thesis], School of Animal Studies, University of Queensland, Queensland, Australia, 2007.

[43] F. Chen, Y. Zhu, X. Dong, L. Liu, L. Huang, and X. Dai, "Lignocellulose degrading bacteria and their genes encoding cellulase/hemicellulase in rumen-a review," Acta Microbiologica Sinica, vol. 50, no. 8, pp. 981-987, 2010.

[44] T. L. Miller and M. J. Wolin, "Bioconversion of cellulose to acetate with pure cultures of Ruminococcus albus and a hydrogen-using acetogen," Applied and Environmental Microbiology, vol. 61, no. 11, pp. 3832-3835, 1995.

[45] G. Chamilos, R. E. Lewis, and D. P. Kontoyiannis, "Lovastatin has significant activity against zygomycetes and interacts synergistically with voriconazole," Antimicrobial Agents and Chemotherapy, vol. 50, no. 1, pp. 96-103, 2006.

[46] L. Galgóczy, T. Papp, G. Lukács, É. Leiter, I. Pócsi, and C. Vágvölgyi, "Interactions between statins and Penicillium chrysogenum antifungal protein (PAF) to inhibit the germination of sporangiospores of different sensitive Zygomycetes," FEMS Microbiology Letters, vol. 270, no. 1, pp. 109-115, 2007.

[47] R. T. Lorenz and L. W. Parks, "Effects of lovastatin (mevinolin) on sterol levels and on activity of azoles in Saccharomyces cerevisiae," Antimicrobial Agents and Chemotherapy, vol. 34, no. 9, pp. 1660-1665, 1990.

[48] T. Vaupotič, P. Veranic, U. Petrovič, N. Gunde-Cimerman, and A. Plemenitaš, "HMG-CoA reductase is regulated by environmental salinity and its activity is essential for halotolerance in halophilic fungi," Studies in Mycology, vol. 61, no. 1, pp. 61-66, 2008.

[49] P. D. Pearce and T. Bauchop, "Glycosidases of the rumen anaerobic fungus Neocallimastix frontalis grown on cellulosic substrates," Applied and Environmental Microbiology, vol. 49, no. 5, pp. 1265-1269, 1985.

[50] N. Yarlett, C. G. Orpin, and E. A. Munn, "Hydrogenosomes in the rumen fungus Neocallimastix patriciarum," Biochemical Journal, vol. 236, no. 3, pp. 729-739, 1986.

[51] A. Bernalier, G. Fonty, F. Bonnemoy, and P. Gouet, "Degradation and fermentation of cellulose by the rumen anaerobic fungi in axenic cultures or in association with cellulolytic bacteria," Current Microbiology, vol. 25, no. 3, pp. 143-148, 1992.

[52] J. L. Song, C. N. Lyons, S. Holleman, B. G. Oliver, and T. C. White, "Antifungal activity of fluconazole in combination with 
lovastatin and their effects on gene expression in the ergosterol and prenylation pathways in Candida albicans," Medical Mycology, vol. 41, no. 5, pp. 417-425, 2003.

[53] L. L. Stoll, M. L. McCormick, G. M. Denning, and N. L. Weintraub, "Antioxidant effects of statins," Drugs of Today, vol. 40, no. 12, pp. 975-990, 2004.

[54] M. Takemoto, K. Node, H. Nakagami et al., "Statins as antioxidant therapy for preventing cardiac myocyte hypertrophy," Journal of Clinical Investigation, vol. 108, no. 10, pp. 1429-1437, 2001. 

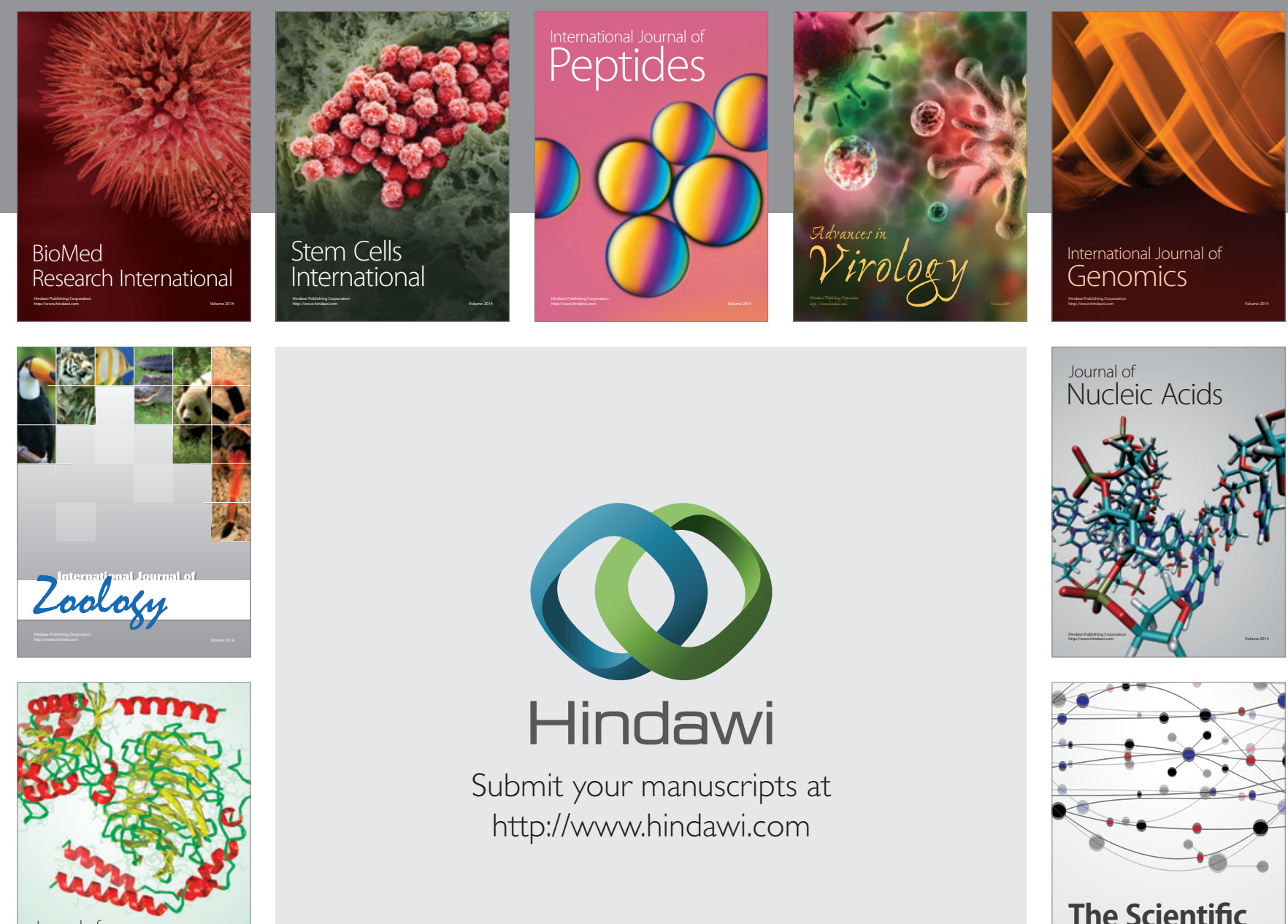

Submit your manuscripts at

http://www.hindawi.com

Journal of
Signal Transduction
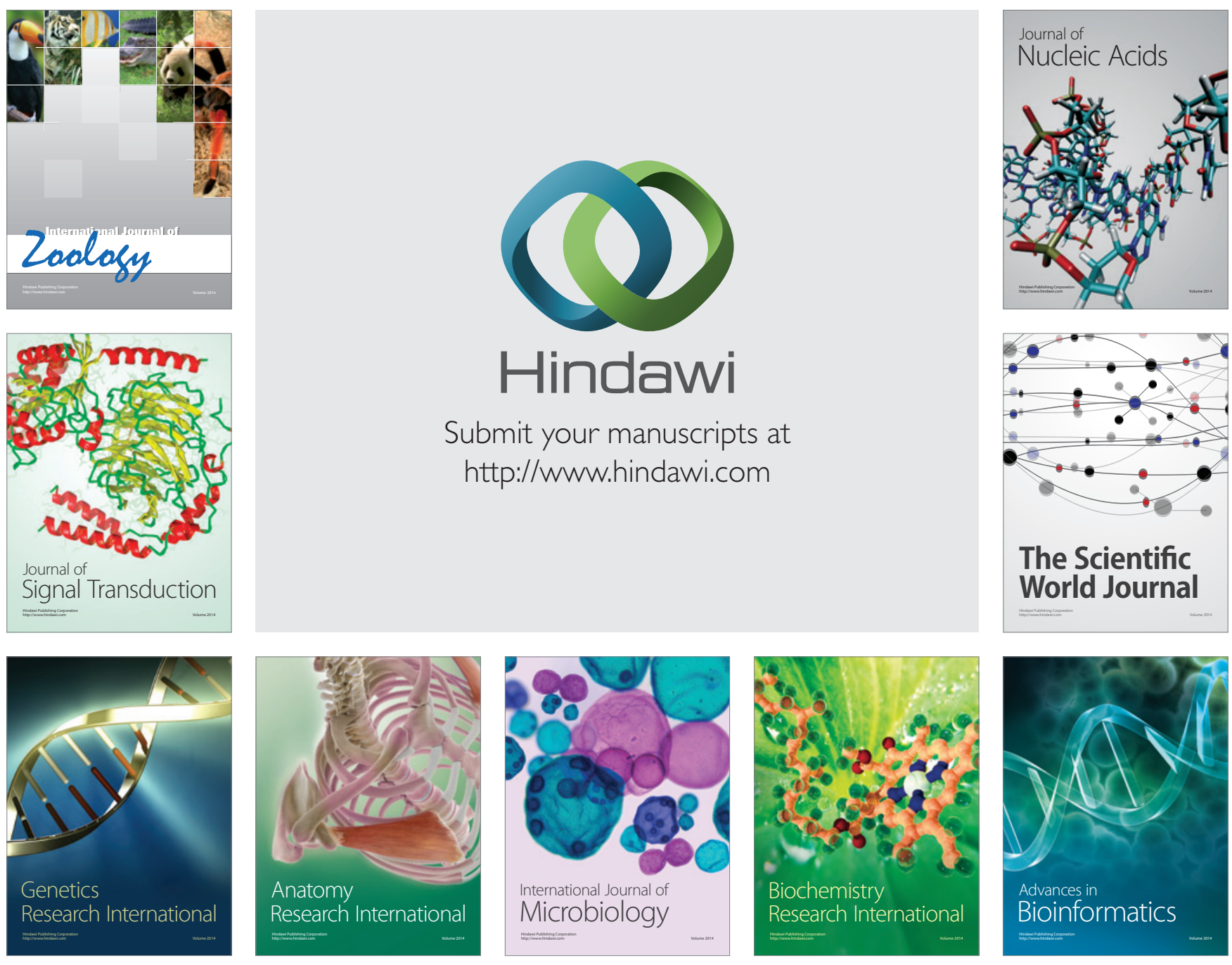

The Scientific World Journal
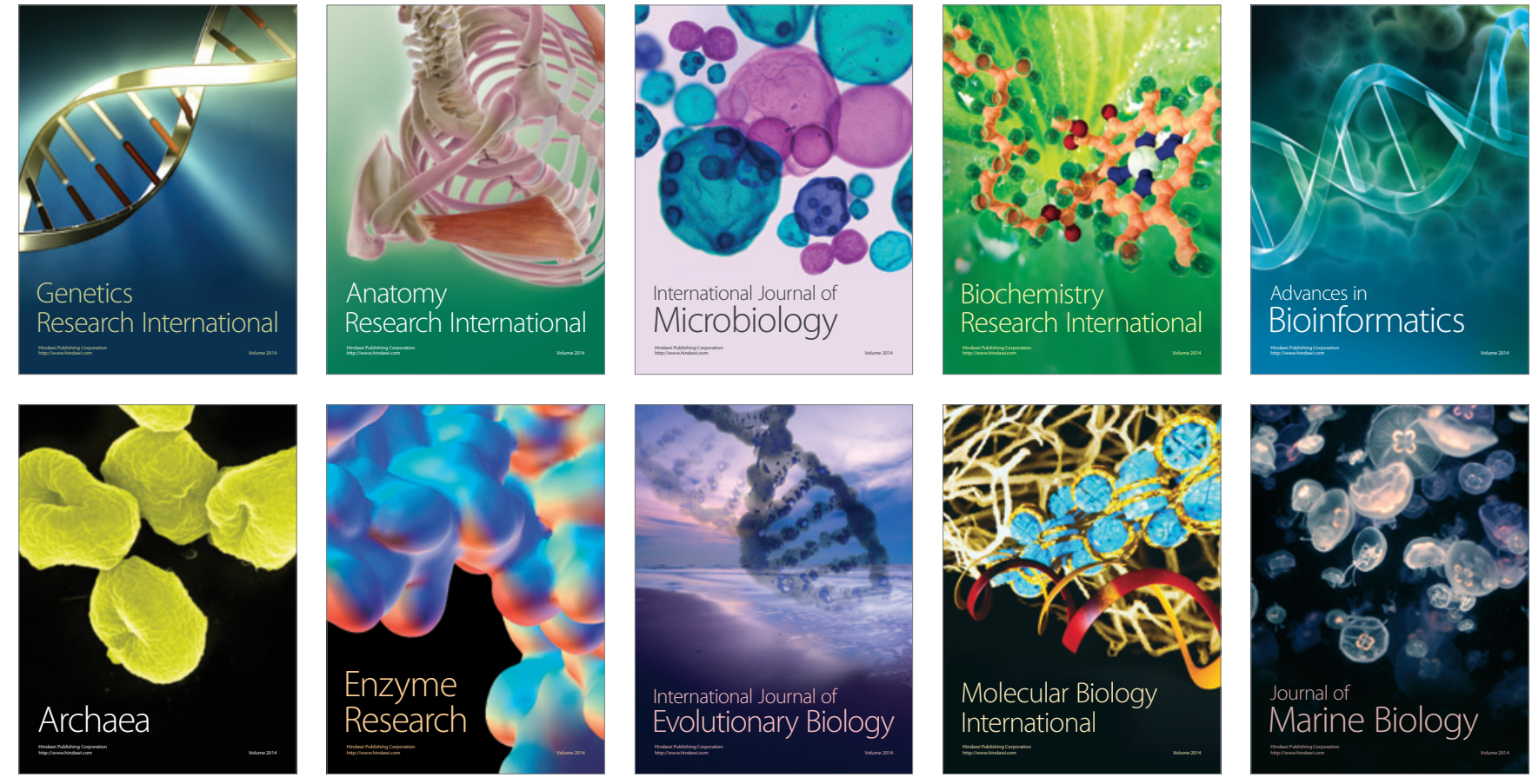